research is done with non-human primates. Four such operations have been conducted in the past 18 months alone by the media-savvy British Union for the Abolition of Vivisection in London, which has also produced an English-language film clipped from Pawel's footage.

The Max Planck Society (MPS) - the Tübingen institute's umbrella organization - was taken off guard by the furore, but it has responded well. It immediately set up an independent expert investigation into conditions for animals in the institute, and published its initial conclusions on 18 September. It said that the film gave a false impression and that the monkeys are particularly well treated at the institute - although veterinary staff are working at the limits of their capacity. The MPS declared that no new research projects will be initiated there until another vet is hired, and until a computer system to record the animals' consumption of food and drink is in place. And rather than insisting that scientists keep their heads down, as it has in the past, it sent the institute's animalwelfare officers to a television debate on 17 September.

More concerning is the fact that the MPS was taken off guard at all. The society has delayed moves by the German scientific community to create an organization to lobby appropriately for animal research and provide professional support in crises such as this one. The moves had in any case been much too slow, given Germany's ambition to become a biomedical powerhouse, which activist campaigns are undermining.

Nature has long advocated for professional animal-research lobbies to combat such campaigns with openness. To battle diseases from Ebola to Alzheimer's - which most of society wants to see conquered - researchers need to use monkeys. It is a difficult issue, and it is understandable that some people think research using non-human primates is too high a price for human health. Some animal activists distort the true facts of such work, or threaten scientists, to promote their cause. Researchers who use monkeys realize that keeping quiet about their work is ineffective. They believe that a more effective - and honest strategy requires them to show the world what they do, and explain why.

The United Kingdom, France and the Netherlands all have national organizations that support and advocate on behalf of animal research.
The powerful US Society for Neuroscience (SfN) and its European counterpart, the Federation of European Neuroscience Societies, have specialist committees. "We all know we need to come out of the closet," says Mickey Goldberg, a neuroscientist at Columbia University in New York, who is chair of the SfN committee of animal research and has spoken in support of the Tübingen scientists.

The Max Planck Institute in Tübingen has, independently of the nervous MPS leadership, done a good job of explaining on its website why it
"German scientists have led the European discussion on animalresearch, but they have not been served well by their organizations." openness about uses monkeys, and how they are cared for. Yet coverage of the recent incident suggests that journalists did not turn to it for information. They might have used an authoritative and independent professional organization - had it existed. Such a group could also have given media training to those who might be targeted by animal activists, or might need to speak up, including research leaders. The representatives who took part in the television debate did a splendid job of defending the Tübingen institute's work, but they did not seize the initiative to match the activists' skills in appealing to the emotions of their audience by explaining that animal research is needed to save lives and alleviate suffering. That is what media training can teach you.

German scientists have led the European discussion on openness about animal research, but they have not been served well by their organizations, which have stalled for time, worried and quarrelled among themselves. The Tübingen debacle must be a wake-up call for them. There are encouraging signs. Last week, the chastened Alliance of Science Organisations in Germany - whose members include the MPS as well as universities and granting agencies - agreed to present plans for an independent organization in the "foreseeable future". It should do this fast. Animal-activist groups in Europe are becoming ever more professional, well organized, coordinated and well funded. The research community needs to match them.

\section{Special interest}

\section{As the Scottish referendum showed, scientists' views can influence political debate.}

$\mathrm{I}$ $\mathrm{t}$ is natural for local and specialist media to seek a relevant position on national and international events. Taken too far, such an approach breeds satire - see the 'local man lost at sea' line, a possibly apocryphal headline from a regional newspaper's report on the sinking of the Titanic. But it can sometimes help to drill into general-interest topics; what is the wider world if not an ever-shifting collection of individual groups of special interests?

To some outside the British Isles (and some inside), last week's decision by the people of Scotland to remain with the United Kingdom merely saw the status quo continue. No iceberg, no shipwreck. Yet there are lessons for scientists; they just have to see them.

As is normal in independence debates, the political fight over Scotland's future was rancorous. And when the result $-55 \%$ no to independence, $45 \%$ yes - came in early on Friday morning, many scientists were among those either elated or mourning a lost opportunity.

It would be going too far to say that debates about how science would fare in an independent nation became central to the decision. But the prospects for research did provide an intriguing and relevant subplot.

Pressure groups on both sides - Academics for Yes and rivals Academics Together - received significant airtime. Heavyweights from UK learned societies were wheeled out to make the case for the union in that most British of political statements: a letter to The Times newspaper. Scientific leaders were presented front and centre as part of the dialogue, and both research and academic freedom in Scottish universities were held by both sides as a prize to value and fight for. In the days leading up to the vote, Alex Salmond, leader of the Scottish government and the independence movement, was attacked over claims that he bullied the head of the University of St Andrews, Louise Richardson, because of her unfavourable (to him) views.

The media, and through them the UK public, were interested in more than just researchers' political opinions and analysis of their funding streams: scientists' daily work was also enlisted. Estimates of the size of the oil reserves in an independent Scotland became frontpage news and even the subject of conspiracy theories, with allegations that the unionist UK government was concealing the true, vast scale of Scotland's potential future wealth.

The story has some way yet to run. Scotland will get extra powers to tax and spend - a sop promised to separatists in the desperate campaigning (see Nature http://doi.org/vvm; 2014). These may even end up resulting in more money for science. But the message from the politicians and the public is already clear: science is important and the views of scientists occupy a privileged place in debates. This may not surprise anyone but it is worth saying, especially at a time when researchers from Australia to Canada feel under-served by their political masters.

Lobbying for science is too important to be left to the science lobby alone, as effective as it can be. Every scientist can do more to talk up the importance of what they do. Researchers who care nothing for $\rightarrow$ NATURE.COM To comment online, click on Editorials at: go.nature.com/xhunqv Scotland and have no comprehension of the differences between the United Kingdom, Great Britain, England, Scotland, Wales and Northern Ireland should still care about this message. Your voices carry great weight: use them. 